\title{
Eleveniszapok mikrobaközössége szezonális változásának vizsgálata kis- és nagyterhelésű szennyvíztisztító telepeken
}

The analysis of the seasonal changes of microbial communities in the activated sludge of small and large wastewater treatment plants

\author{
D. SIPOS ${ }^{1}$, R. MISETA2 ${ }^{2}$ A. ZSENI ${ }^{3}$ \\ ${ }^{1}$ Győr-Moson-Sopron Megyei Kormányhivatal Győri Járási Hivatal Agrárügyi és Környezetvédelmi Főosztály \\ Környezetvédelmi Osztály, siposdor@gmail.com \\ 2Pannon-Víz Zrt., Minőségvizsgáló Laboratórium, miseta.roland@pannon-viz.hu \\ ${ }^{3}$ Széchenyi István Egyetem, Audi Hungaria Járműmérnöki Kar, Környezetmérnöki Tanszék, zseniani@sze.hu
}

\begin{abstract}
Absztrakt. Tanulmányunkban az eleveniszapos szennyvíztisztítási rendszerek aerob medencéjében kialakult mikrobaközösség összetételételében történő változásokat követjük nyomon a hőmérséklet függvényében, egy nagyés két kisméretü illetve -terhelésü szennyvíztisztító telep eleveniszap mintáiban. Munkánk során 14 hónap adatait dolgoztuk fel. A minták elemzését illetve az adatok feldolgozását követően fény derült az ökológiai rendszer teljesítményére és évszakos devianciájára. A statisztikai eredmények azt mutatják, hogy a nagyobb telep mikrobaközösség-összetételében a szezonalitás kevésbé megfigyelhető, ami alapján feltételezzük, hogy a nagyobb kapacitású eleveniszapos medencékben stabilabb mikrobaközösség alakult ki. Emellett a kapott eredmények alapján összefüggéseket kerestünk az ökoszisztéma alkotói, az időjárás változása, illetve az eleveniszapok tisztítási hatásfoka között.
\end{abstract}

Abstract. In our research the seasonal changes of the microbial communities in the activated sludge of one large and two small wastewater treatment plants are observed and analysed. During the research, 14 months of data were processed. After the sample analysis and data processing, the research revealed the efficiency of the ecological system, and also showed the seasonal changes of the community structures. The results of the statistical analysis show, that the seasonality is less observable in the case of the larger system. Presumably, the larger bioreactors have more stable microbial composition. In addition, we searched for more connections between the components of the ecological system, the changing in the weather, and also in the efficiency in the process for treating wastewater.

\section{Bevezetés}

Kutatómunkánk során a Pannon-Víz Zrt. üzemeltetési területén lévő banai-, téti-, illetve győri szennyvíztisztító telepek levegőztető műtárgyainak eleveniszapját alkotó mikroba-közösségek 
szezonális változását követtük nyomon. Arra voltunk kíváncsiak, hogy egy nagy- és két kisméretű illetve -terhelésű és egymástól távol lévő szennyvíztisztító telep eleveniszapos mikrobaközösségében a vizsgált időszakban (2015. január - 2016. február) észlelhető-e szezonális változás. Mivel az eleveniszap a külső környezeti hatásokra (pl.: hőmérséklet) rendkívül érzékeny, feltételezzük, hogy az eleveniszap mikrobiális összetétele szezonális változást mutat. Emellett valószínűsíthető, hogy a győri szennyvíztisztító telep méretéből adódóan stabilabb eleveniszap-közösséggel rendelkezik, így kevésbé befolyásolják a műtárgyakban élő ökoszisztémát a külső környezeti hatások. További felvetés volt az, hogy az eleveniszap eukarióta közösség-szerkezete összefüggést mutat-e a tisztítási hatásfok szezonális változásával.

A fentiek alapján munkánk során azt a célt tűztűk ki, hogy az Egységes Mikrobiológiai Vizsgálati és Kiértékelő Rendszer (EMVIR) segítségével megvizsgáljuk és nyomon követjük két kiskapacitású és egy nagykapacitású szennyvíztelep eleveniszap közösségeinek szezonális (évszakos) változását.

\section{Szakirodalmi áttekintés}

A biológiai szennyvíztisztítás meghatározó eljárása az eleveniszapos technológia, amely a kommunális szennyvíztisztítást illetően a legelterjedtebb hazánkban. A lebontást végző mikroorganizmusok pehely formájában, a szennyvízben alakulnak ki, a szerves anyag lebontását úszva, lebegve végzik, aerob körülmények között, intenzív levegőztetés mellett [1-3]. A levegőztető berendezésben a folyamatok eredményeként a víz szervesanyag-tartalma lecsökken, a mikroorganizmusok mennyisége viszont megnövekszik.

A szerves anyagok lebontását nagy szaporodási sebességgel rendelkező aerob heterotróf baktériumok végzik, így ez a folyamat viszonylag rövid időt vesz igénybe. Ezzel szemben a nitrifikáció lassú folyamat, az aerob nitrifikáló mikroorganizmusok (Nitrosomonas, Nitrobacter) lassan szaporodnak, és nagyon érzékenyek a környezeti tényezők hirtelen változására, ill. a mérgező anyagokra [4]. Ennek következtében a nitrifikáció biztosítása az egyik legnehezebb feladat a nitrogén eltávolítása során.

Az eleveniszapokban lejátszódó nitrifikáció-hőmérséklet függésével számos kutatás foglalkozik. A hamburgi települési szennyvíztisztító telepről származó eleveniszap mintákban nitrit-oxidáló baktériumok jelenlétét vizsgálták elektronmikroszkópiával, tenyésztéssel, illetve tenyésztéstől független molekuláris módszerekkel. A kutatás során sikerült tenyésztésbe vonniuk egy addig ismeretlen, hideg környezethez adaptálódott nitrit-oxidáló baktériumot, amely a Nitrotoga arctica fajhoz állt legközelebbi filogenetikai rokonságban. Emellett megállapították, hogy a nitrit-oxidálók összetétele komplexebb, mint korábban feltételezték, és a populáció szerkezete alapvetően a hőmérséklet hosszú távú változásaira reagál [5]. Yu és munkatársai $12^{\circ} \mathrm{C}$ és $22^{\circ} \mathrm{C}$-on végzett laboratóriumi vizsgálatokkal 2 SBR-rendszerű szennyvíztisztító baktériumközésségét hasonlították össze molekuláris biológiai módszerekkel. Eredményeikkel azt mutatták ki, hogy a heterotróf baktériumközösségekben nemzetség szintjén kimutatható volt a hőmérséklet hatása, azonban a bakteriális összetétel törzs szintjén hasonló szerkezetet mutatott [6]. Young és munkatársai biofilmek nitrifikáló közösségeit vizsgálták, mely során kimutatták, hogy a baktériumközösségek $20^{\circ} \mathrm{C}$-on szignifikánsan változatosabbnak bizonyultak az $1^{\circ} \mathrm{C}$-os működéshez képest [7]. Habár $1^{\circ} \mathrm{C}$-on kevésbé 
változatos volt az összetétel, de még ezen az alacsony hőmérsékleten is 2000 baktériumfajt mutattak ki.

A nitrifikáció lejátszódását követő denitrifikáció anaerob környezetben valósul meg. A denitrifikáló baktériumok az oxigén helyett a nitrátot használják fel az energiatermelő folyamataikban, a nitrátredukció végeredményeként pedig szén-dioxid és nitrogén gáz képződik [8].

Az eleveniszapok mikrobiális összetétele alapvetően meghatározza a biológiai tisztítás hatékonyságát, mivel az eleveniszapban élő aerob és anaerob heterotróf, illetve nitrifikáló baktériumok végzik a szennyvíz szervesanyag-tartalmának lebontását, a nitrifikációt, illetve a denitrifikációt. Ez az ökoszisztéma a külső környezeti hatásokra (oldott oxigénkoncentráció, hőmérséklet, toxikus anyagok, turbulens hatások stb.) azonban igen érzékeny, ezért ha kedvezőtlen hatások érik, az eleveniszap mikrobiális összetétele megváltozik, a biológiai tisztítás hatásfoka csökken. Az eleveniszapok rendszeres mikroszkópos vizsgálatával nyomon követhetjük a faji összetételben bekövetkező változásokat, így az ökoszisztéma romló vagy javuló állapotváltozása későbbi üzemeltetési problémákat (iszaphabzás, ülepítési problémák, anaerob szervesanyag-lebontás) vetíthet előre [8, 9].

Két egymástól távoli és eltérő kapacitású szennyvíztelepről származó eleveniszap baktériumközösségeit és azok dinamikáját egy éves periódusban vizsgáló kutatás eredményei alapján a nagykapacitású bioreaktor biodiverzitása szignifikánsan magasabb volt, mint a kisebb kapacitású bioreaktoré [10]. Emellett kimutatták, hogy a nagykapacitású bioreaktor esetében a közösségdinamika kevésbé volt kifejezett, mint a kisebb kapacitású szennyvíztelepen. A nagyobb kapacitású bioreaktorban tehát egy ökológiailag stabilabb és fajgazdagabb mikrobaközösség alakult ki, míg a kisebb bioreaktor eleveniszapjában a külső környezeti tényezőkre érzékenyebb, instabilabb és kisebb biodiverzitású baktériumközösség volt a jellemző.

\section{Anyag és módszer}

Kutatásaink során feldolgoztuk és elemeztük a 2015. január - 2016. február időszak folyamán vizsgált eleveniszap minták eredményeit. A heti rendszerességgel érkező eleveniszap mintákat a Pannon-Víz Zrt. Minőségvizsgáló Laboratóriumában az EMVIR vizsgálati módszere alapján [8, 9, 11] dolgoztuk fel. A mintákat borításos módszerrel, Olympus BX 51 TF fáziskontraszt mikroszkóppal vizsgáltuk, majd az EMVIR rendszere szerint jellemeztük. Az EMVIR, azaz Egységes Mikrobiológiai Vizsgálati és Kiértékelő Rendszer, a következő feladatokat látja el: a fonalasság mértékének meghatározása, az iszapszerkezet meghatározása, valamint a faji összetétel meghatározása. Ezek alapján az EMVIR üzemeltetési javaslatokat tesz az iszapszerkezet stabilitására és a biológiai tisztítás hatásfokának növelésére, úgymint az oldott oxigénszint emelése vagy csökkentése, az iszaptartózkodási idő emelése vagy csökkentése, a biológiai medencébe érkező szennyvízmennyiség csökkenése vagy növelése. Tanulmányunkban az eleveniszapok eukarióta közösség-összetételének, valamint a fonalas baktériumok szezonális eloszlás vizsgálatának eredményét mutatjuk be, ezért az EMVIR vizsgálati módszerének és előírásainak csak a tanulmány szempontjából releváns részeit mutatjuk be röviden.

Az eleveniszap-közösségek szezonális változását a közösségalkotók gyakorisági értékeinek évszakos átlagai és a fonalasság fajonkénti alakulásának idősoros vizsgálatával, valamint főkomponens 
analízissel végeztük el. A kapott eredmények alapján összefüggéseket kerestünk az ökoszisztéma alkotói, az időjárás változása, illetve az eleveniszapok tisztítási hatásfoka között.

\subsection{Mintavétel}

A minták a banai, téti és győri szennyvíztisztító telepről érkeztek. A kb. 3000 lakosegyenérték tényleges terhelésű banai szennyvíztelep műtárgyai a homokfogóval, majd egy anoxikus előtisztító műtárggyal kezdődnek, amelyben szervesanyag-lebontás és a denitrifikáció megy végbe. Ezt követi egy egyesített biológiai mútárgy, ami a levegőztető medencéből és az utóülepítőből áll. Az eleveniszapos foszfor- és nitrogéneltávolítást követően az iszapot víztelenítik, és a mezőgazdaságban tápanyagpótlás céljából hasznosítják. A mintavétel a levegőztető medencéből történt.

A kb. 5000 lakosegyenérték tényleges terhelésű téti szennyvíztisztító telepen két OMS mütárgyban párhuzamosan zajlik a szennyvíztisztítás. Az OMS mútárgyakban anaerob, anoxikus és levegőztető terek elkülönülve találhatók. A tisztított szennyvíz a levegőztető térből az utóülepítő mútárgyba kerül. A biológiai eleveniszapos nitrogén- és foszforeltávolítást követően az iszapot víztelenítik, majd a mezőgazdaságban hasznosítják. Mintavétel mindkét OMS műtárgy levegőztető teréből történt (Tét I., Tét II.).

A győri teljes kiépítettségű, folyamatos üzemű telep, kb. 175 ezer lakosegyenértékű tényleges terheléssel. A mechanikai előtisztítást biológiai tisztítás követi, amely anoxikus medencékből, levegőztető medencékből és utóülepítőkből áll. Végül az iszapot anaerob módon stabilizálják és víztelenítik. Mintavétel a 4 párhuzamosan működő levegőztető medencéből történt (Győr I., Győr II., Győr III., Győr IV.).

Az eleveniszap mintákat mind a hét mútárgy esetén a levegőztető medence elfolyó végéből vettük, mivel itt a biológiai tisztítás közel véget ér. A mintavételezéskor rögzítésre került az iszap hőmérséklete is. A mintavétel és szállítás teljes egészében az EMVIR előírások alapján történt. A mintákat állandó $4-6^{\circ} \mathrm{C}$-on szállítottuk és maximum $24 \mathrm{~h}$-ig tároltuk a biológiai vizsgálatok előtt.

\subsection{Mikromorfológiai vizsgálatok}

A mikromorfológiai vizsgálatok során az EMVIR előírásai szerint jártunk el. Az eleveniszap mikromorfológiai elemzését mikroszkópos kép alapján végeztük el. A minta-előkészítés szabályai szerint, első lépésként a mintákat rázással homogenizáltuk, majd ezt követően borításos módszerrel vizsgáltuk a preparátumokat. A baktériumokat és eukarióta egy-, illetve többsejtúeket Olympus BX 51 TF fáziskontraszt mikroszkóppal tanulmányoztuk 100-szoros, illetve 200-szoros nagyításon. A mikromorfológiai vizsgálatok során az eleveniszap mikroszkópos képével jellemezhető az ökológiai rendszer állapota. Ennek során az alábbiakban felsorolt paramétereket vizsgáljuk: cellazárás, pehely szerkezete, pelyhek mérete, pelyhek alakja, fonalasság mértéke, fonalak alakja, fonalak hatása az iszapszerkezetre, valamint az indikátor organizmusok száma. Az indikátor organizmusok négy nagy csoportba rendezhetőek, úgymint baktériumok, helytülő egysejtűek, szabadon úszó egysejtűek és többsejtű szervezetek.

Az EMVIR előírásai szerint általunk vizsgált indikátor szervezeteket az 1. táblázatban összegeztük. 


\begin{tabular}{|c|c|c|c|}
\hline Baktériumok & Helytülő egysejtúek & $\begin{array}{c}\text { Szabadon úszó } \\
\text { egysejtúek }\end{array}$ & $\begin{array}{c}\text { Többsejtú } \\
\text { szervezetek }\end{array}$ \\
\hline $\begin{array}{l}\text { Szabad baktériumok } \\
\text { Spirillum spp. } \\
\text { Spirochaeta spp. } \\
\text { Zoogloea spp. } \\
\text { Thiothrix spp. } \\
\text { Sphaerotilus spp. } \\
\text { Nocardia spp. } \\
\text { Microthrix parvicella } \\
\text { Typ 021N } \\
\text { Typ 0041 } \\
\text { Beggiatoa spp. }\end{array}$ & $\begin{array}{l}\text { Thuricola spp. } \\
\text { Carchaesium spp. } \\
\text { Epistylis spp. } \\
\text { Opercularia spp. } \\
\text { Vorticella campanula } \\
\text { Vorticella convallaria } \\
\text { Vorticella microstoma } \\
\text { Zoothamnium spp. } \\
\text { Suctoria spp. }\end{array}$ & $\begin{array}{l}\text { Amphileptiade } \\
\text { Aspidisca cicada } \\
\text { Aspidisca lynceus } \\
\text { Chilodonella spp. } \\
\text { Coleps spp. } \\
\text { Colpidium spp. } \\
\text { Euplotes spp. } \\
\text { Holophrya spp. } \\
\text { Metopus spp. } \\
\text { Paramecium spp. } \\
\text { Spirostomum teres } \\
\text { Trochilis minuta } \\
\text { Kitartóképlet (ciszta) } \\
\text { Üres szárak } \\
\text { Szaporodóképlet } \\
\text { (pete, leváló, bimbózó, } \\
\text { osztódó sejtek stb.) } \\
\text { Csupasz amőba } \\
\text { Házas amőba } \\
\text { Bodo spp. } \\
\text { Egyéb ostorosok } \\
\text { Peranema spp. }\end{array}$ & $\begin{array}{l}\text { Gombafonalak } \\
\text { Rotaria spp. } \\
\text { Egyéb kerekesférgek } \\
\text { Medveállatka } \\
\text { Oligochaeta spp., } \\
\text { Nematoda spp. }\end{array}$ \\
\hline
\end{tabular}

1. táblázat: Indikátorszervezetek listája az EMVIR kategóriák szerint

\subsection{Az adatok feldolgozása}

Az eleveniszapok közösség-összetételét és szezonális változását a gyakorisági illetve előfordulási értékek alapján készített idősoros ábrák segítségével tanulmányoztuk, a három szennyvíztisztító telep vizsgálatba vont mind a 7 mútárgya esetén.

$\mathrm{Az}$ iszapszerkezet változását fentieken kívül főkomponens analízissel is nyomon követtük. A főkomponens analízis (Principal Component Analysis, későbbiekben PCA) egy statisztikai módszer, mellyel háttérváltozók hatása vizsgálható nagy adathalmazra (jelen esetben a mikrobaközösségre). A PCA diagramon egyszerre több dimenzióban több háttérváltozó jeleníthető meg, az x, y tengelyeken a két legmeghatározóbb komponensekkel. A módszer segítségével a levegőztető medencék iszapszerkezetének szezonális változását követtük nyomon, az indikátorszervezetek, mint háttérváltozók felhasználásával. A főkomponens analízishez a PAST (Paleontoligical Statistics V2.08) szoftvert használtuk [12], és azokat a változókat (indikátor szervezeteket: közösségalkotó prokariótákat és eukariótákat) vettük számításba, amelyek a minták legalább 10\%-ában jelen voltak.

Az EMVIR az online felületén felvitt adatok alapján (pehelyszerkezet, a pelyhek alakja, a pelyhek mérete, a fonalak gyakorisága, a fonalak alakja, a fonalak hatása a pehelyszerkezetre, a jelen levő indikátorszervezetek azonosítása és gyakoriságuk a mintában) a rendszer algoritmusának segítségével jellemezte a biológiai tisztítás állapotát. Ennek során a szénlebontást (zavart vagy zavartalan), a nitrifikációt (zavart vagy zavartalan) és az iszapterhelést (magas vagy normális) értékelte az algoritmus [11]. 


\section{Eredmények}

Az eleveniszapok összetételének szezonális változását a közösségalkotók évszakonkénti gyakorisági értékeire (1., 8., 14. ábra), a fonalasság fajonkénti alakulása (2., 10., 15. ábra), az iszaphőmérséklet (3., 11., 16. ábra), valamint a főkomponsens analízis vizsgálat (PCA) (7., 12., 17. ábra) eredményeire támaszkodva mutatjuk be az egyes szennyvíztisztító telepeken.

\subsection{A banai eleveniszap szezonális változása}

A banai minták esetében a közösségalkotók összetételében fellelhető volt szezonalitás (1., 2. ábra). A banai eleveniszapban a fonalasság fajonkénti alakulását jól láthatóan a szezonális változás jellemezte: a téli hónapokban, illetve a tavaszi melegedés időszakában tavasz végéig, amikor az iszaphőmérséklet $15^{\circ} \mathrm{C}$ alá csökkent (3. ábra) a Microthrix parvicella (4. ábra) jelent meg a telepen, majd 3-as, illetve 4-es gyakorisággal elszaporodott, mialatt a többi fonalas baktériumfajt visszaszorította (2. ábra).

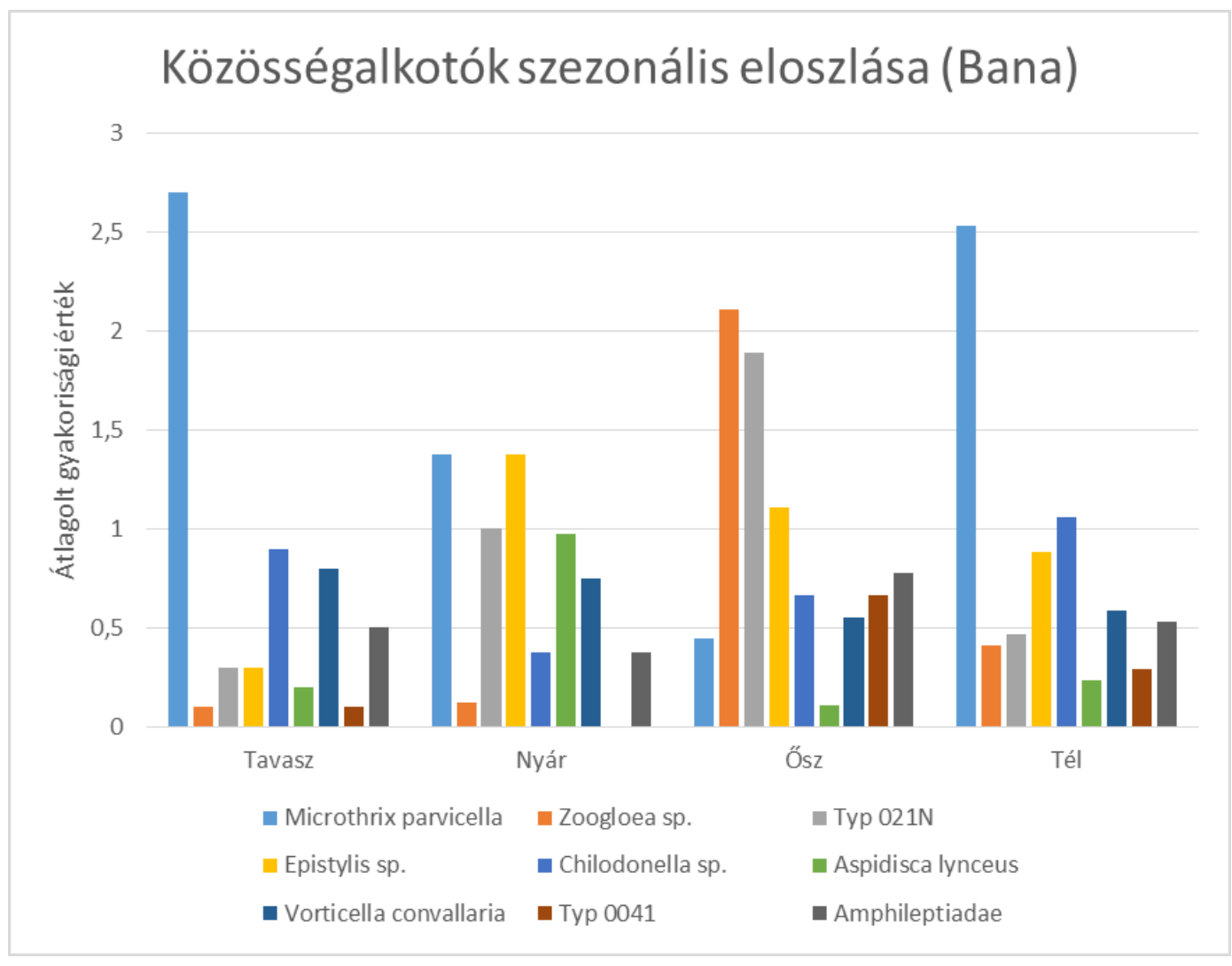

1. ábra: Közösségalkotók szezonális eloszlása (Bana).

A Microthrix parvicella egy fonalas baktérium, amely az eleveniszapos szennyvíztisztítási rendszerekben iszapfelúszást és habzást okoz [13]. Elsőként Pasveer mutatta ki eleveniszapból 1969ben ezt a szennyvíziszapban közönségesen előforduló változó üzemállapotot indukáló baktériumot [14]. A Microthrix parvicella alapvetően aerob baktérium, mely tág tűrőképességgel rendelkezik az oldott oxigént illetőleg, de tenyészthető microaerofil körülmények között is. 


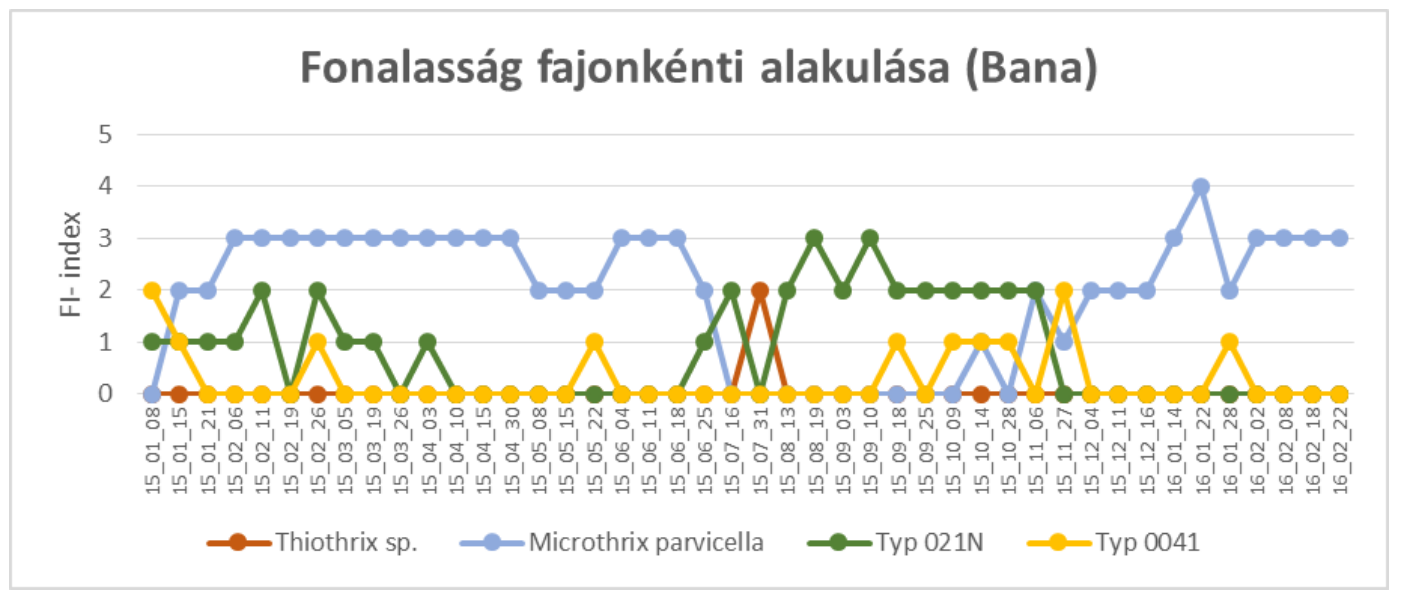

2. ábra: A fonalasság fajonkénti alakulása a banai eleveniszap-mintákban, 2015. január - 2016. február.

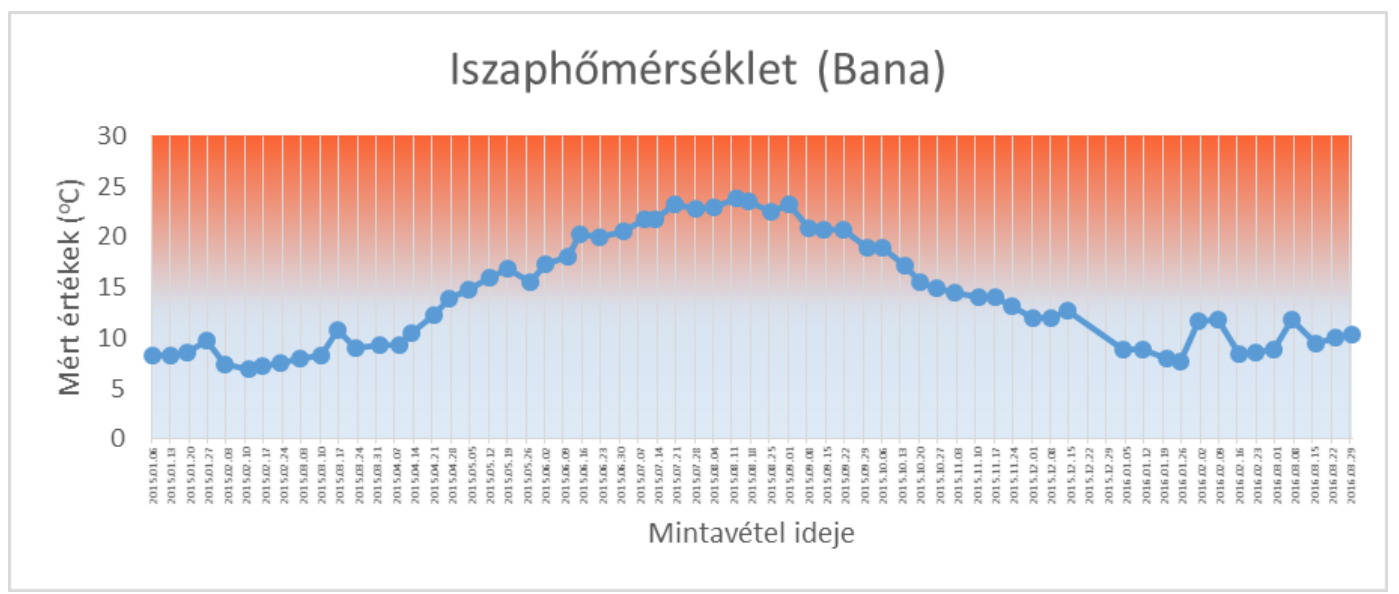

3. ábra: Iszap-hőprofil, Bana 2015. január - 2016. február.

A nyári időszakban, amikor az iszaphőmérséklet $18^{\circ} \mathrm{C}$ fölé emelkedett, a Microthrix parvicella visszaszorult, és a Typ $021 \mathrm{~N}$ fonalas kénbaktérium (5. ábra) váltotta. A Typ 021N a Thiothrix nemzetséghez tartozó taxon, melynek egyik tiszta törzstenyészetét Thiothrix eikelboomi-ként ismerjük [15]. A Typ 021N-fonal 3-as gyakorisággal tetőzött augusztus végén, szeptember elején, majd fokozatosan csökkent a fonalasság gyakorisága. Bár a Typ 0041-es baktériumfonal is megjelent a banai eleveniszapban, megjelenésük eseti volt, és nem volt domináns egyik esetben sem. A Typ 0041-es fonalas baktérium azon fonalas baktériumokhoz tartozik, amely iszapfelúszást okozhat. Ez a baktérium rendszertanilag változatos baktérium-konzorciumból áll, ugyanis mind a baktériumfonalak, mind pedig az elágazások rendszertanilag különböző taxonokból állnak [16]. A fonalasság-változása alapján feltételezhető, hogy a lehűlt banai eleveniszapban vagy az iszapterhelés volt alacsony, vagy magas volt a zsír-és olajterhelés, ami a Microthrix parvicella elszaporodását, illetve a többi fonalas faj visszaszorulását eredményezte. Feltételezzük, hogy a nyári időszakban az iszapterhelés megváltozott, vélhetően a nyári időszakban a magas iszapterhelés hatására anoxikus körülmények alakulhattak ki, amelyek kedveztek a Typ 021N kénbaktériumok elszaporodásának. A Typ 021N fonalasok az iszap novemberi lehűléséig jelen voltak. Az ezt követő hideg időszakban a kénbaktériumokat ismét a Microthrix parvicella váltotta. A Zoogloea spp. (6. ábra) őszi kiugrása elsősorban üzemeltetési problémára, vagy a csapadékosabb őszi időjárásra utal. Az Aspidisca lynceus nyári időszakbeli 
magasabb átlag gyakorisági értékének magyarázata feltehetően a magasabb hőmérsékletű iszapban élő nitrifikáló baktériumok elszaporodása, amelyekkel ez a faj táplálkozik.

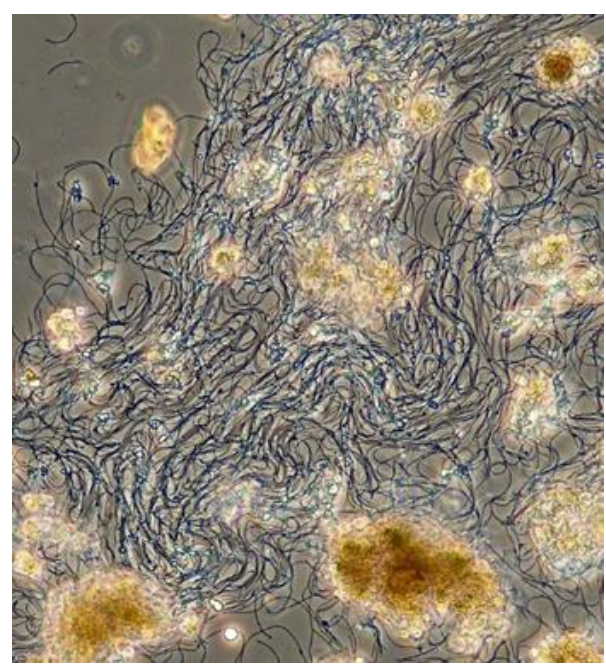

4. ábra: Microthrix parvicella (fénykép: $R$. Miseta).

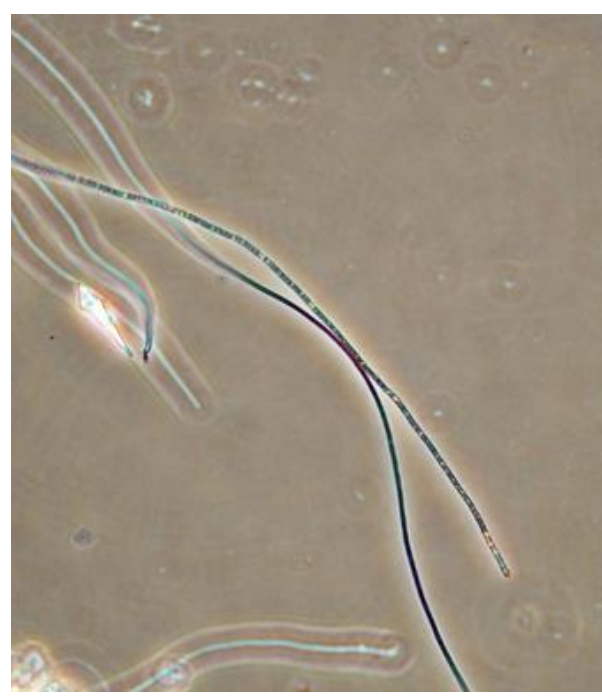

5. ábra: Typ 021N (fénykép: R. Miseta).

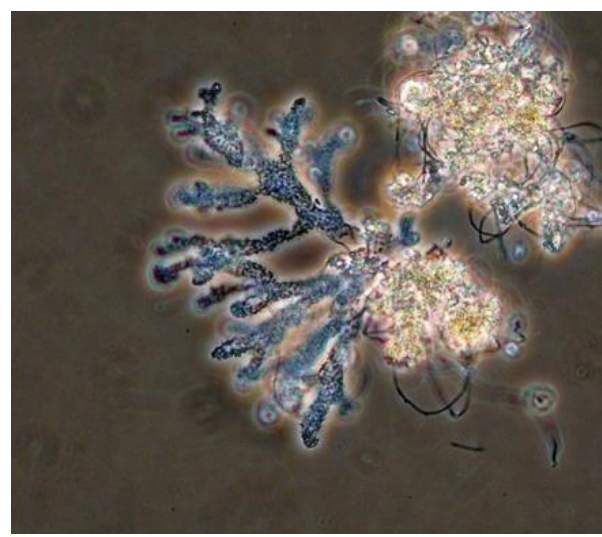

6. ábra: Zoogloea spp. (fénykép: R. Miseta). 
A főkomponens analízis vizsgálat eredményét a 7. ábra mutatja. A diagram két tengelyén megjelenített első két főkomponens a minták varianciájának 27\%-át magyarázta (16,1\% : 10,6\% arányban). A 7. ábrán látható, hogy a január-áprilisi szezonális minták, valamint a szeptemberi-októberi minták két különböző csoportba szerveződnek, és az első főkomponens mentén elkülönültek egymástól. A januáráprilisi mintákra a Microthrix parvicella dominanciája volt jellemző magas gyakorisági értékekkel, míg az őszi csoport szezonális mintáiban a Typ 021N-fonalas baktérium, illetve emellett a szintén magas iszapterhelést jelző Zoogloea sp. telepes baktérium jelent meg magas gyakorisági értékekkel. A többi közösségalkotó szezonális eloszlása egyenletes volt egy kiugró esetet leszámítva, amikor az Epistylis sp. nyeles csillós egysejtû néhány esetben (dec. 11., dec. 16.) kiugróan magas gyakorisággal volt észlelhető. Érdekes, hogy a nyeles csillósok közül a Carchaesium sp. inkább a hideg időszakban, a Microthrix parvicella fonalas baktériumok elszaporodásával egy időben jelent meg, míg a többi nyeles csillós egysejtű (Vorticella fajok) szezonális eloszlása sokkal egyenletesebb volt.

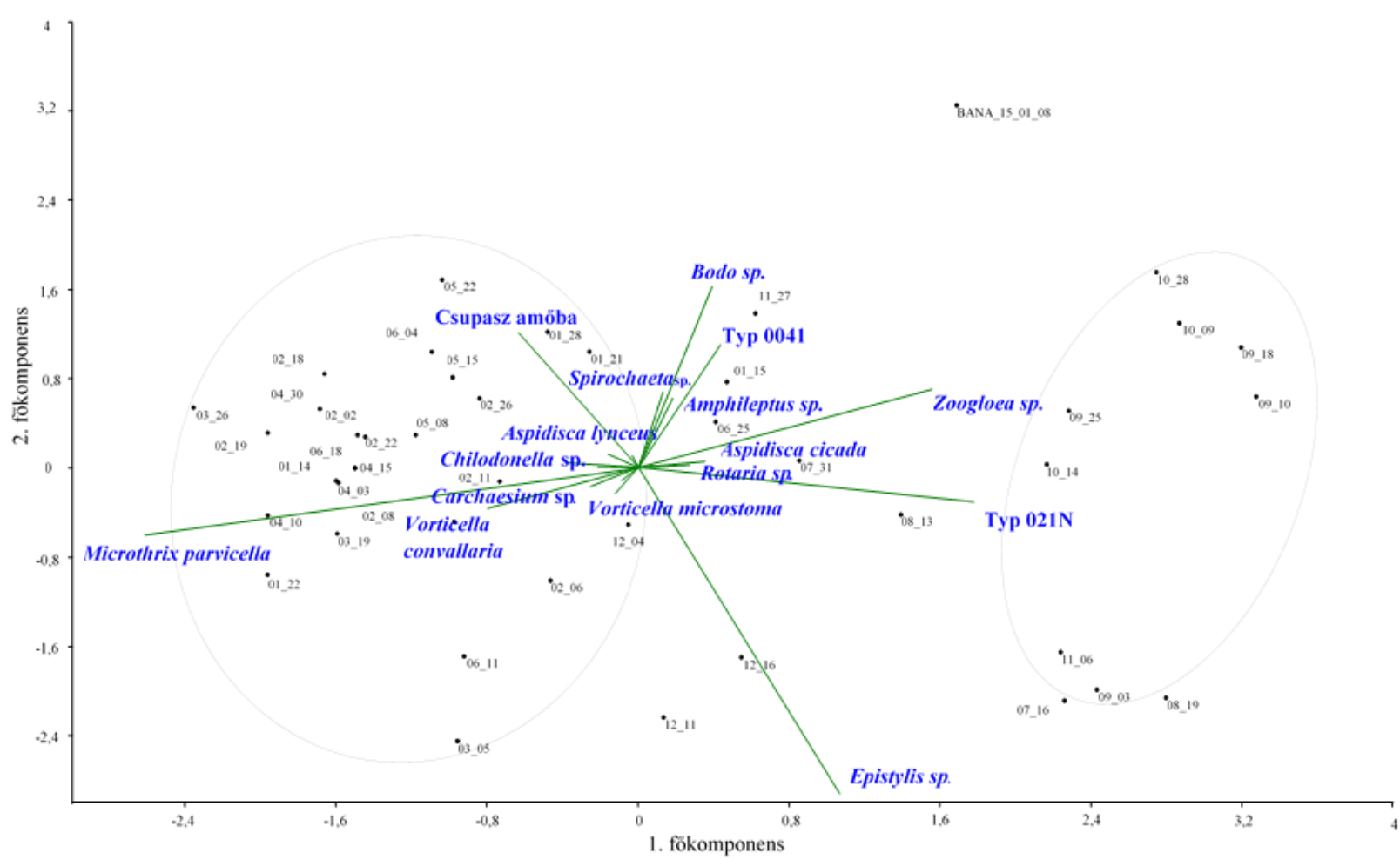

7. ábra: A banai eleveniszap-minták elhelyezkedése a közösségalkotó mikroorganizmusok előfordulása és gyakorisága alapján.

\subsection{A téti eleveniszap szezonális változása}

A Microthrix parvicella eloszlása ugyancsak szezonalitást mutatott a téti eleveniszapban (8. ábra), azonban a nyári-őszi időszakban a helyét a Typ 0041 fonalas baktérium vette át. A Chilodonella sp. és az Euplotes sp. megjelenése a tél-tavasz időszakban volt jellemző, ezzel szemben a Rotaria sp. (9. ábra) 
a nyár-őszi időszakban volt gyakori, ami feltehetően a magas iszapkort és a megfelelő oldott oxigénmennyiséget jelezte.

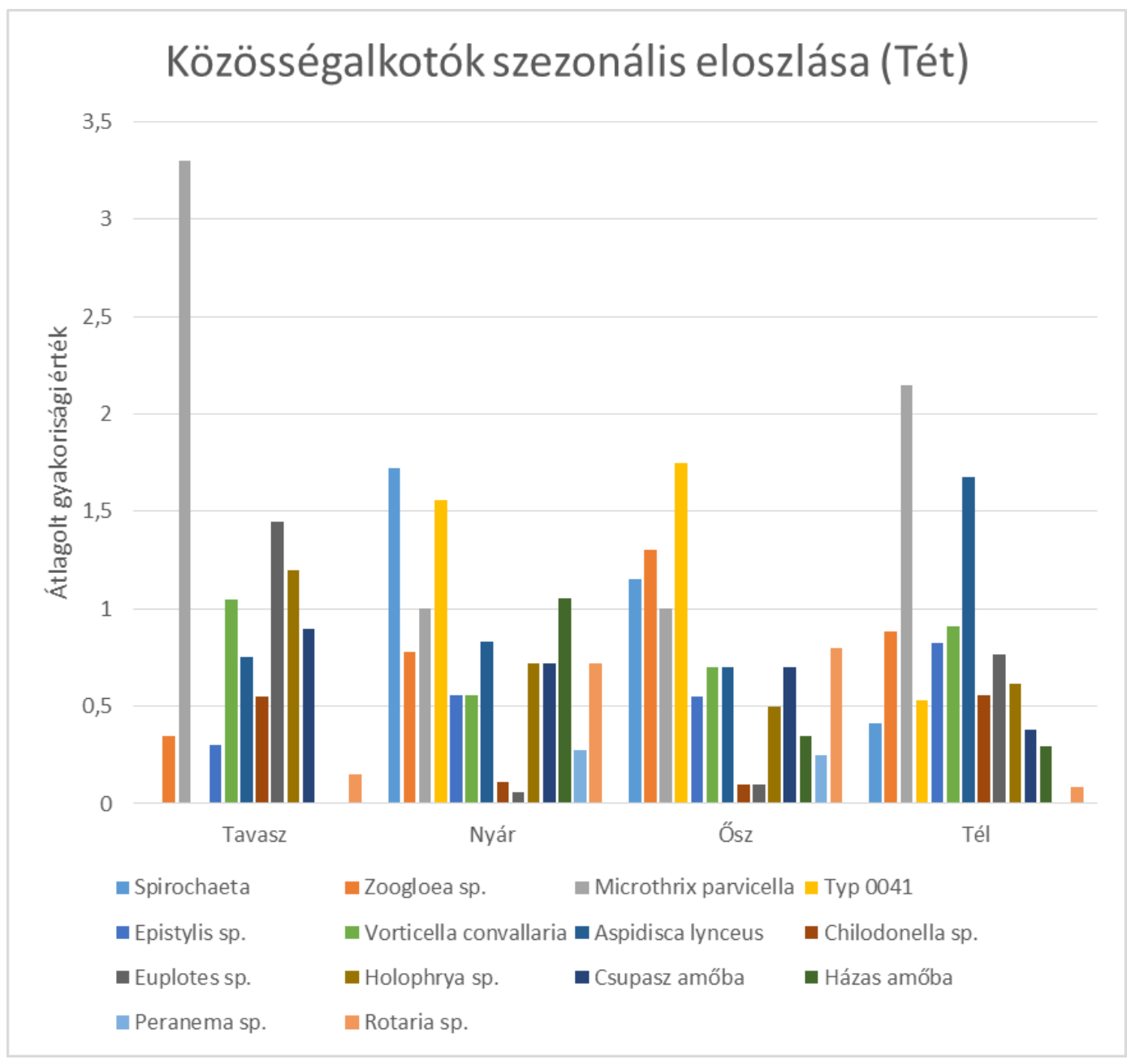

8. ábra: Közösségalkotók szezonális eloszlása (Tét).

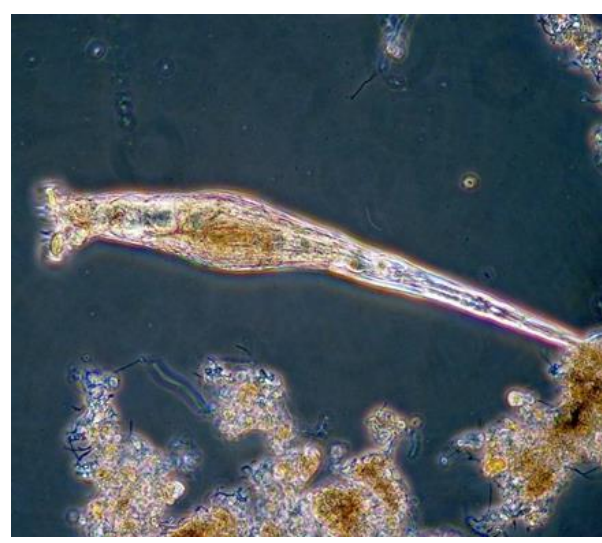

9. ábra: Rotaria sp. (fénykép: R. Miseta).

A téti ikerműtárgyakban a fonalasság szezonális dinamikája szintén jól szemügyre vehető volt (10. ábra). Hasonlóan a banai mintákhoz, a téti eleveniszapban is hideg és meleg időszaki fonalasságváltozás volt megfigyelhető. A novemberi iszap-lehúlés kezdetével (11. ábra) a Microthrix parvicella 
fonalas baktériumok 2-es és 3-as fonalasság-gyakorisággal voltak jellemezhetők. Sőt, kora tavasszal mennyiségük a 4-es gyakoriságú szintre emelkedett. Nyár elején, amikor az eleveniszap hőmérséklete $15^{\circ} \mathrm{C}$ fölé emelkedett, megjelentek a Typ 0041-es baktériumfonalak is, és fokozatosan átvették az életteret a Microthrix parvicella baktériumok felett. A nyári fonal-gyakoriság egy esetben sem érte el a 3-as szintet. Ebből arra következtetünk, hogy a nyári időszakban nem voltak iszapülepedési problémák, valamint a szennyvíztelepen alacsony, illetve közepes volt az iszapterhelés.

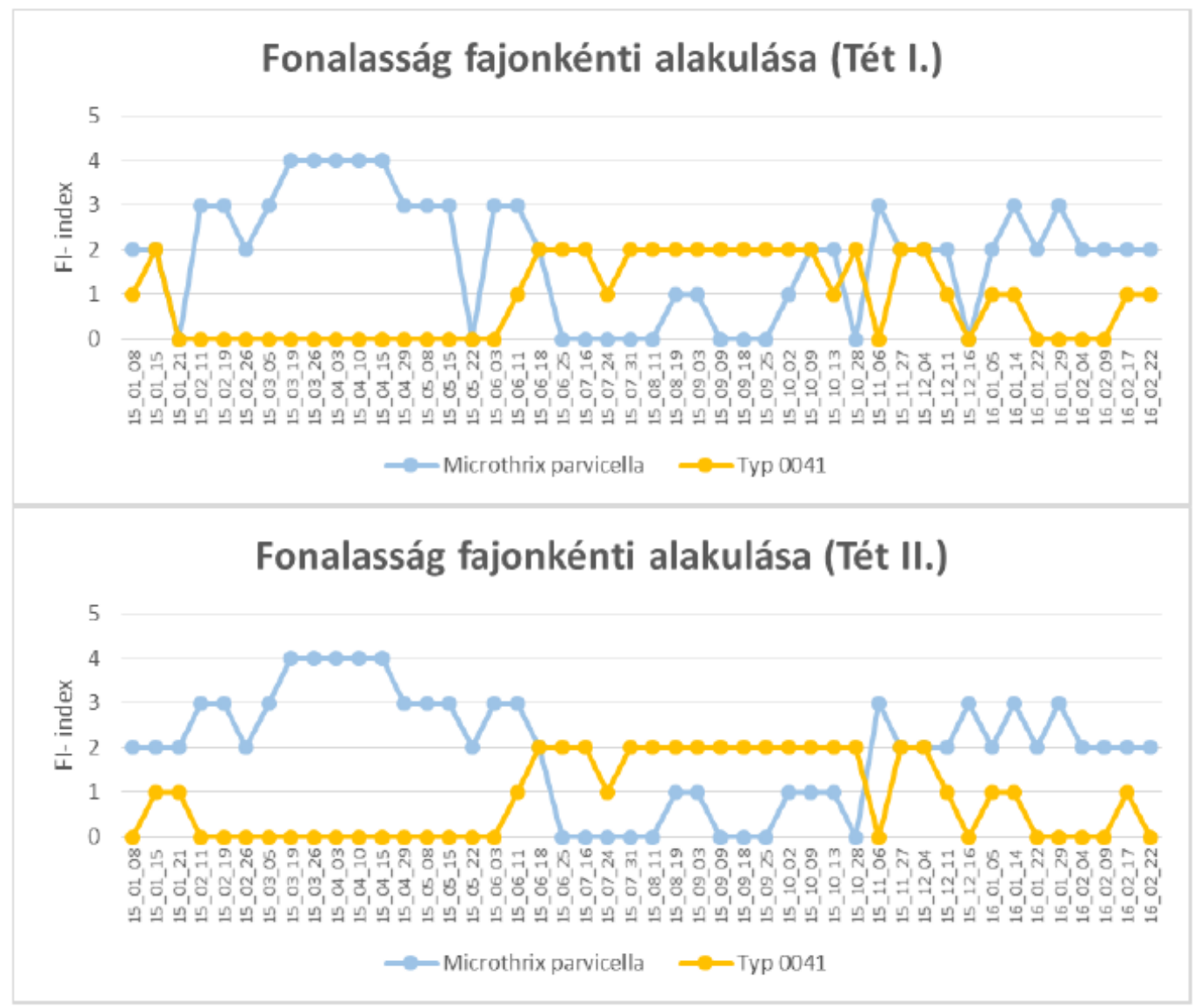

10. ábra: A fonalasság fajonkénti alakulása a Tét I-es és Tét II-es mútárgy eleveniszap-mintákban, 2015. -február.

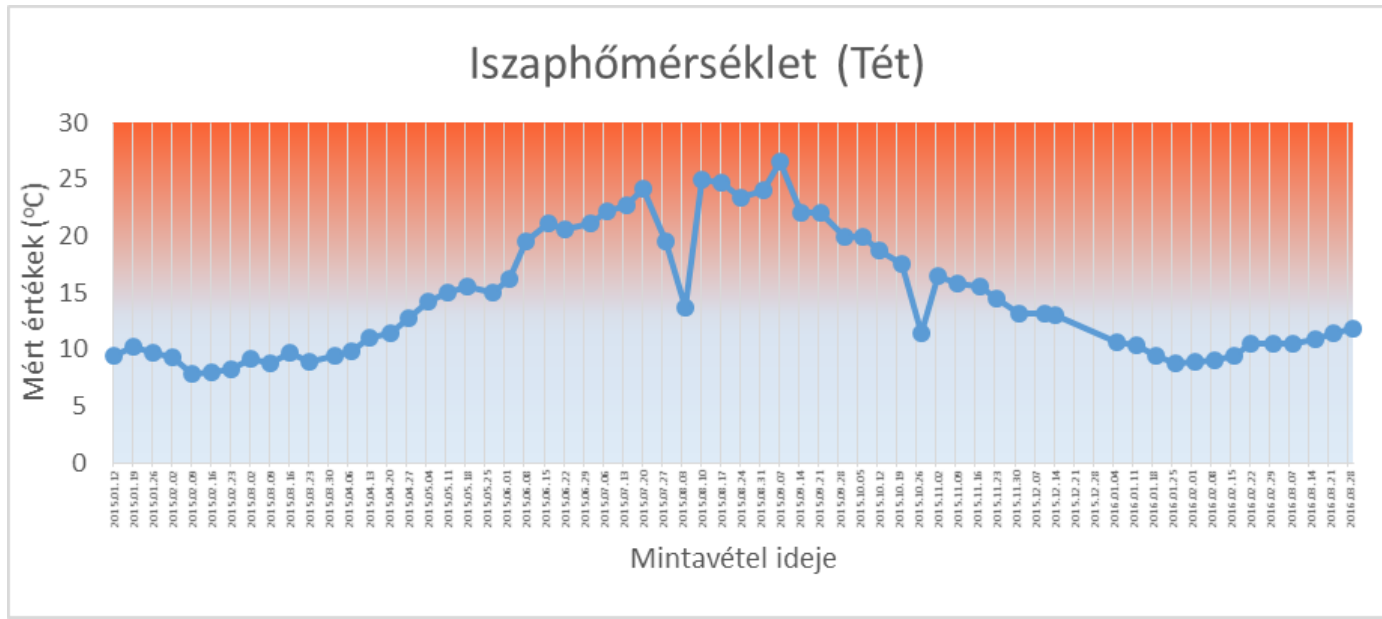

11. ábra: Iszap-höprofil, Tét 2015. január - 2016. február. 
A téti I-es és II-es OMS mútárgyból származó szezonális minták eloszlását egy közös PCA-diagramon szemléltettük (12. ábra). Az első két főkomponens a minták 38\%-át magyarázta (27,7\% : 10,6\% arányban). Látható, hogy a minták az első főkomponens mentén jól elkülönültek egymástól. A hideg időszakban (január-április) vett minták külön csoportot képeztek a nyári és őszi mintáktól (júniusszeptember). A $15^{\circ} \mathrm{C}$ alatti hőmérsékletű eleveniszapokat leginkább a Microthrix parvicella fonalas baktérium jellemezte, melyet a Vorticella microstoma nyeles csillós egysejtű kísért. A Vorticella microstoma jelenléte megnövekedett ammónium-tartalmat jelez, tehát a két mikroorganizmus együttes jelenléte alapján feltételezhető, hogy a téti OMS mútárgyakban a téli-kora tavaszi időszakban az alacsony iszapterhelés alacsony pehelyaktivitással és a nitrifikációs folyamatok hiányával párosult. A téli időszakban néhány alkalommal megjelentek egyéb egysejtű csillós protozoonok is, úgymint az Aspidisca lynceus, Euplotes spp., Vorticella convallaria. A nyári mintákban ugyanakkor a Typ 0041-es fonalakat leginkább a többsejtű szervezetek (Rotaria spp., egyéb kerekesférgek, Oligochaeta spp., Nematoda spp.),valamint házas amőbák kísérték. Ezen közösségalkotók elsősorban a jó üzemállapot és magas iszapkor indikátorai. Emellett megfigyelhető a Spirochaeta spp. szabadonúszó baktériumok (13. ábra) tömeges elszaporodása is, melyek rossz levegőztetésű, pangó víztereket és oxigénhiányos állapotot jeleznek. Az eleveniszapot alkotó egyéb protozoonok szezonális elkülönülése a téti mintákban kevésbé volt megfigyelhető.

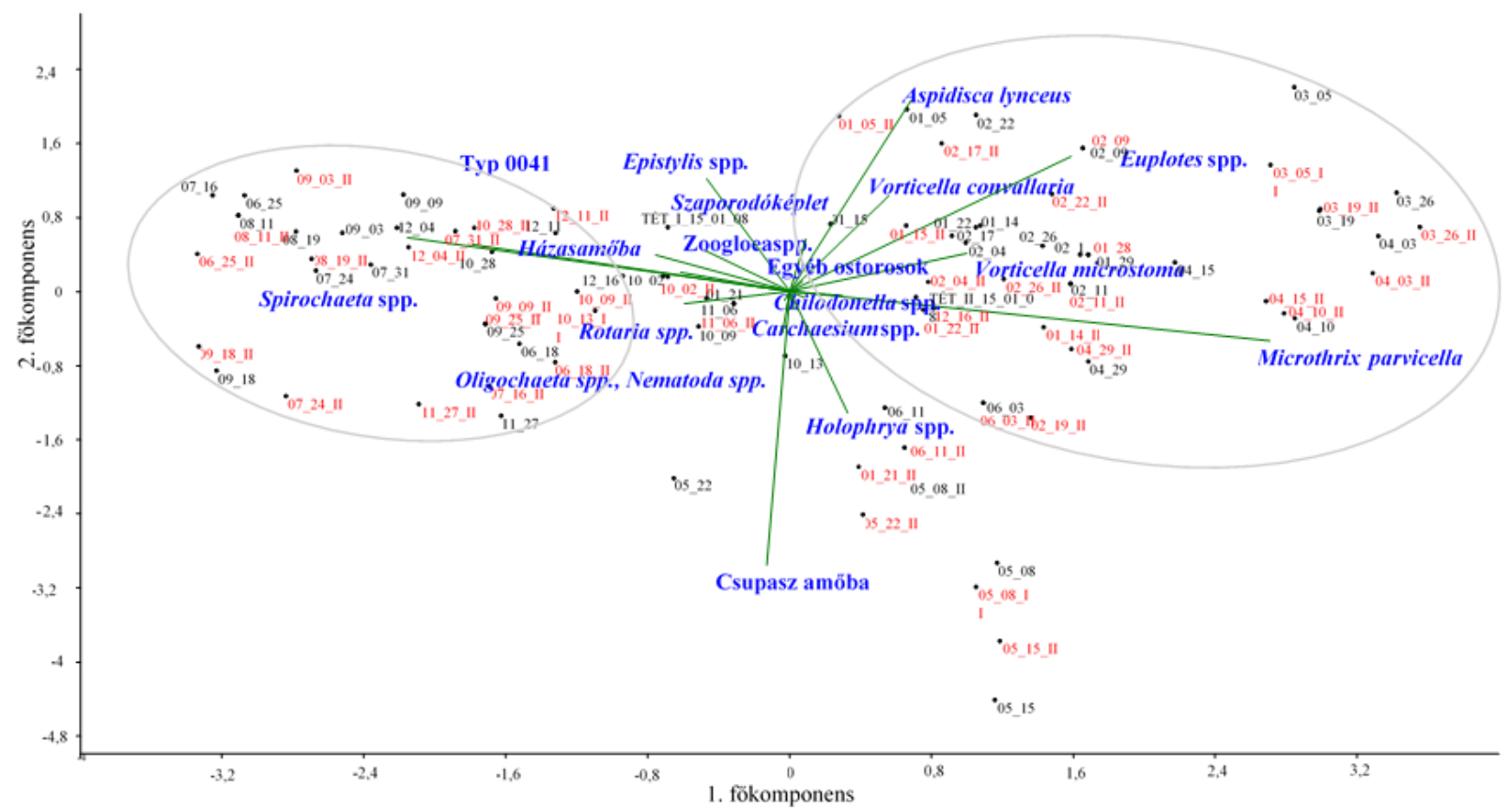

12. ábra: A téti eleveniszap-minták elhelyezkedése a közösségalkotó mikroorganizmusok előfordulása és gyakorisága alapján. 


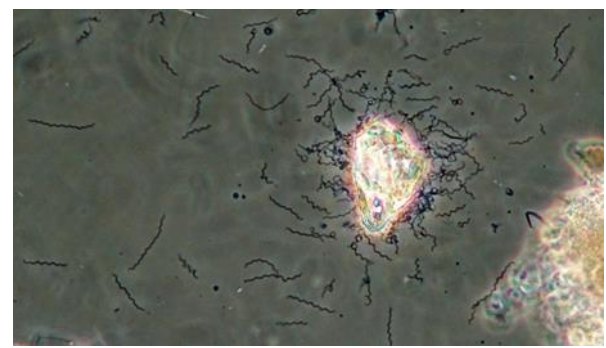

13. ábra: Spirochaeta sp. (fénykép: R. Miseta).

\subsection{A győri eleveniszap szezonális változása}

A győri mintákban a Microthrix parvicella magasabb gyakorisági értékkel volt jellemző a hidegebb időszakban (14. ábra). A többsejtű szervezetek (Oligochaeta sp., Nematoda sp., Rotaria sp.) magasabb iszaphőmérsékletű időszakban voltak jellemzőek (ugyanúgy a téti telep esetében is), amely magasabb iszapkorra illetve magasabb oldott oxigénre utal, ezzel szemben a Holophrya sp. a hidegebb időszakban szerepelt magasabb gyakorisági átlagértékkel.

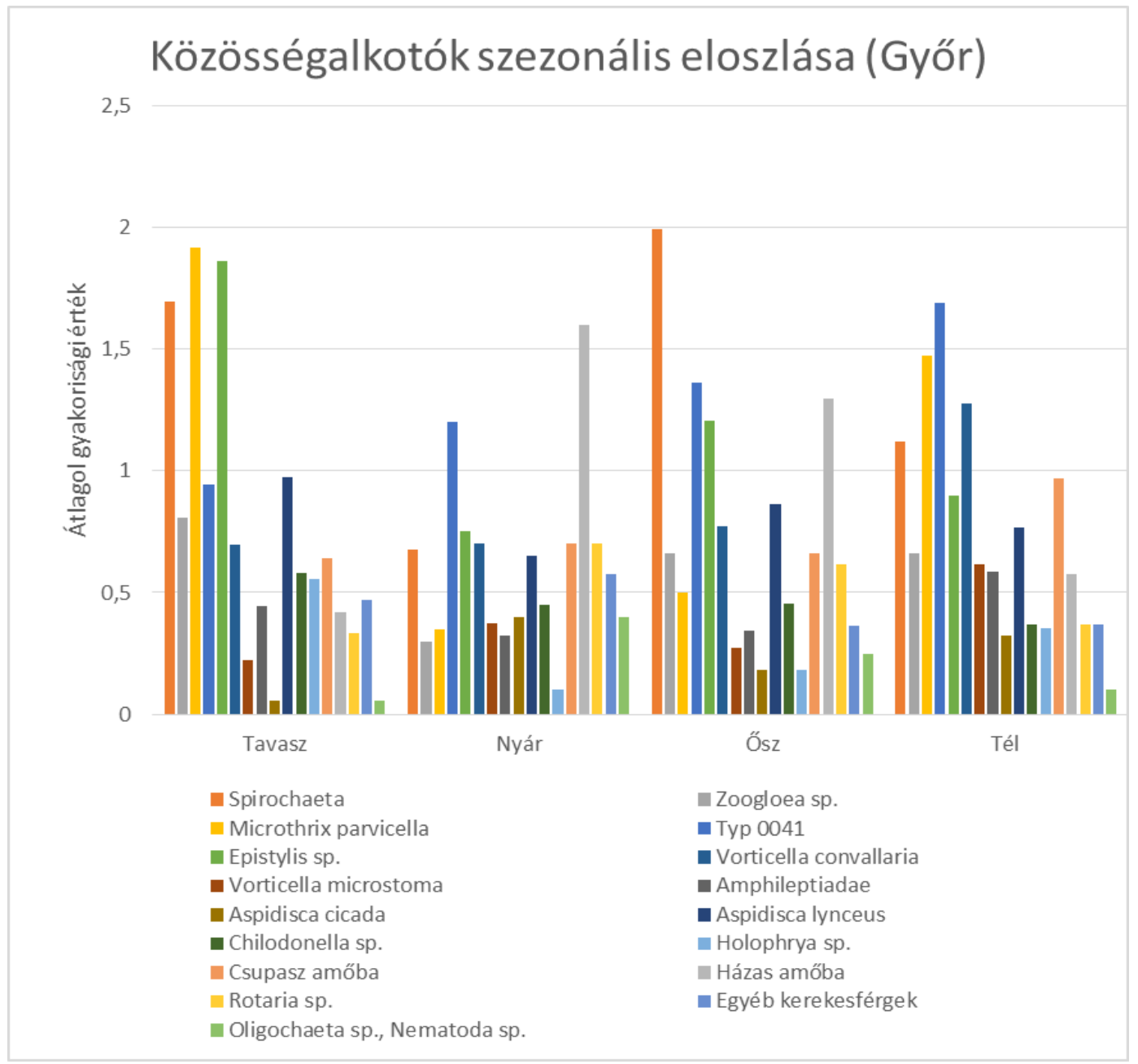

14. ábra: Közösségalkotók szezonális eloszlása (Győr). 
A győri eleveniszap-medencékben a fonalasság évszakos váltakozása szintén megfigyelhető volt, bár sokkal kisebb mértékben, mint a kisméretű szennyvíztelepek esetén. A 4 mütárgy fonalassággrafikonjain (15. ábra) jól látható, hogy a hideg hónapokban (16. ábra) az alacsony iszapterhelés indikátoraiként ismert Microthrix parvicella a Typ 0041-es fonallal együttesen volt jelen, alacsony gyakorisággal. Ezt követően a meleg időszak beköszöntével a Microthrix parvicella visszahúzódott a pelyhekbe, és a nyári hónapokra teljesen eltűnt az eleveniszapokból. A Typ 0041-es fonalak ugyanakkor folyamatosan jelen voltak a szezonális mintákban mind a négy mútárgy esetében, de csupán 1-es gyakorisággal. A négy mútárgyra ugyancsak jellemző volt a Typ 021N fonalas kénbaktériumok eseti előfordulása is, alacsony gyakoriság-értékkel. A Typ 021N fonalak megjelenése tehát sem magas iszapterhelésre, sem egyéb üzemzavarra (ipari szennyezés, toxikusság, pangó vízterek) nem utalt a győri szennyvíztelepen. 


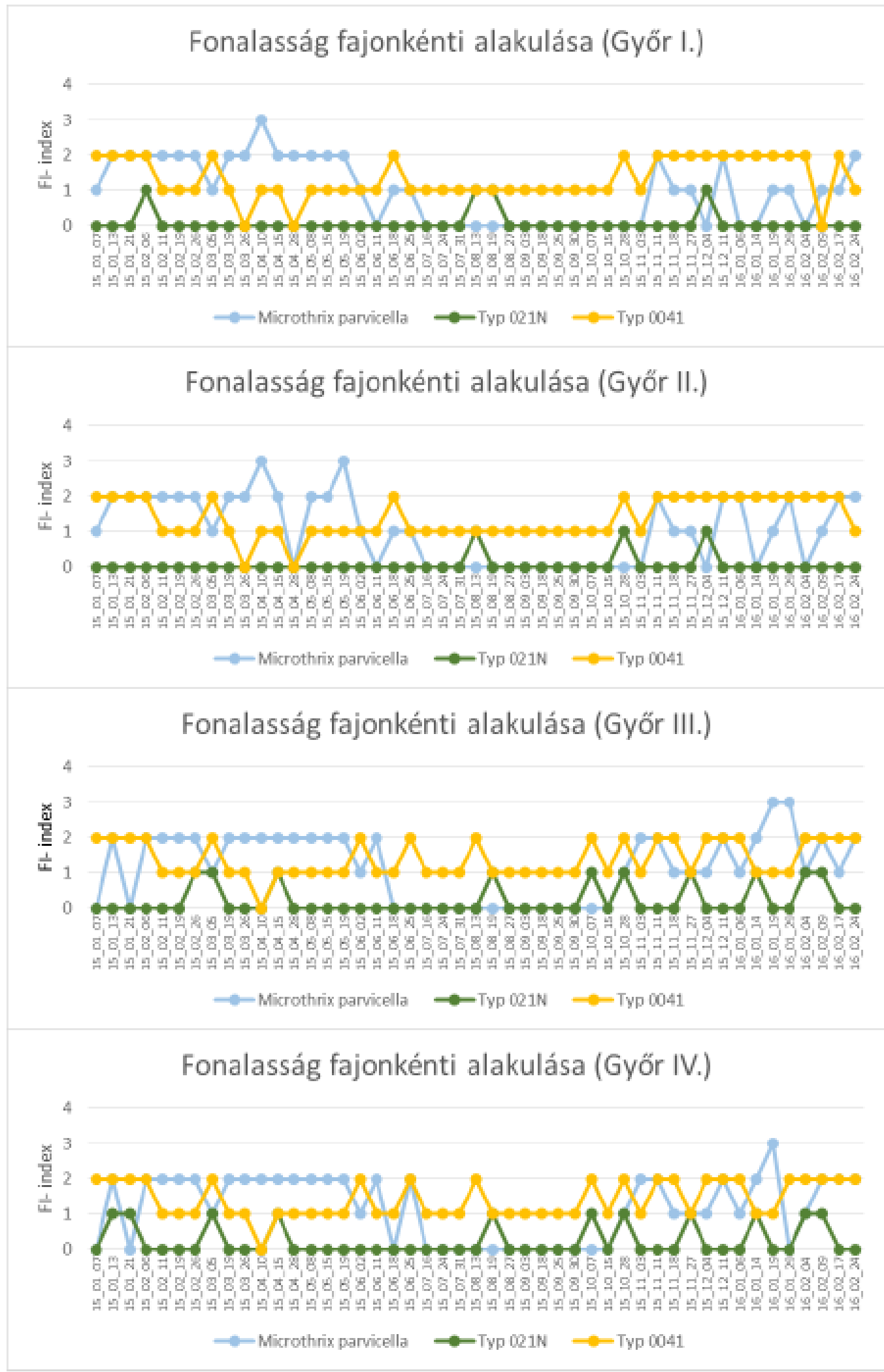

15. ábra: A fonalasság fajonkénti alakulása a Győr I-es, II-es, III-as és IV-es mütárgy eleveniszap-mintákban, 2015. január - 2016. február. 


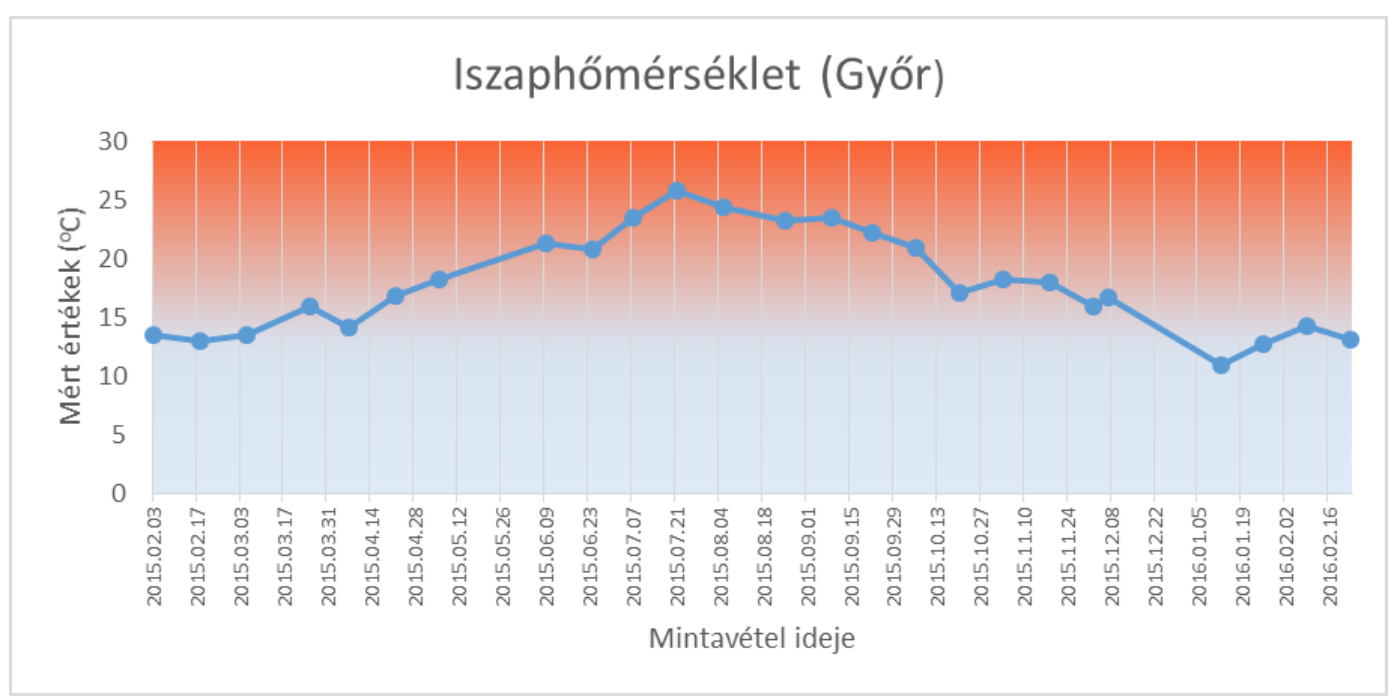

16. ábra: Iszap-hőprofil, Tét 2015. január - 2016. február.

A győri I-es, II-es, III-as és IV-es levegőztető medencék eleveniszap-közösségeit szintén egy közös PCAdiagramon hasonlítottuk össze (17. ábra). Az első két főkomponens a minták varianciájának csupán 32\%-át magyarázta (19,2\% : 13,1\% arányban). Az indikátorszervezetek évszakos eloszlása a kis telepekkel ellentétben egyik győri biológiai medencében sem volt kimutatható. Néhány közösségalkotó, mint a Microthrix parvicella, Spirochaeta sp., illetve az Epistylis sp. viszonylag nagyobb gyakorisággal volt jelen a többi közösségalkotóhoz képest (17. ábra). Az eukarióta közösségalkotók többsége azonban az origó pont körül helyezkedett el, tehát a csillós, ostoros és nyeles csillós egysejtűek, valamint a többsejtűek hasonló gyakorisággal és egyenlő eloszlással voltak jelen a szezonális mintákban évszaktól függetlenül, ami a külső hőmérséklet által kevésbé befolyásolt, stabil közösségszerkezetre utal.

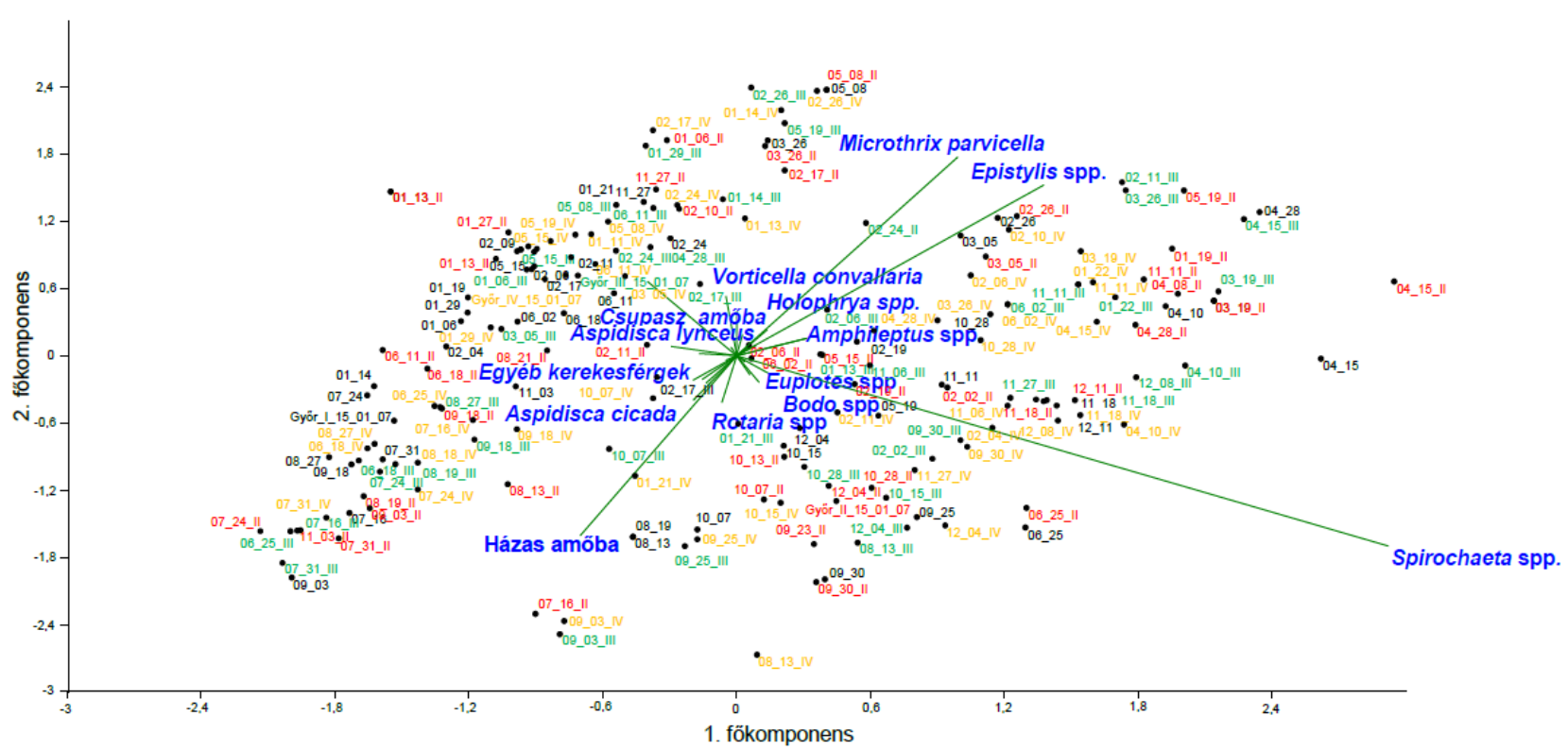

17. ábra: A győri eleveniszap-minták elhelyezkedése a közösségalkotó mikroorganizmusok előfordulása és gyakorisága alapján. 


\section{4. Értékelés}

Az eleveniszap-minták felvitt adatai alapján az EMVIR online rendszere az algoritmus segítségével jellemezte a biológiai tisztítás állapotát. Ennek során értékelte a szénlebontást (zavart vagy zavartalan), a nitrifikációt (zavart vagy zavartalan), valamint az iszapterhelést (magas vagy normális). A jellemzéseket időrendi sorrendbe téve az alábbiakat állapítottuk meg.

A tisztítási hatásfok szezonális változásában a tavaszi-téli illetve a nyári-őszi minták nitrifikáció értékei között vonható párhuzam, amelynek magyarázata az, hogy az eleveniszapban jelen lévő nitrifikáló baktériumok (Nitrosomonas, Nitrobacter) számos környezeti hatásra érzékenyek, így a hőmérsékletre is. A 18., 19. és 20. ábrákon látható, hogy a hidegebb hónapokban a nitrifikáció mindhárom szennyvíztisztító telepen nehezebben ment végbe, illetve egyes esetekben teljes mértékben leállt a nitrifikáló baktériumok munkája.

A szénlebontásban szezonális változás nem volt nyomon követhető egyik telepen sem, mivel a szénlebontást végző pehelyképző baktériumok a környezeti hőmérsékletre kevésbé érzékenyek (18., 19., 20. ábra).

$\mathrm{Az}$ iszapterhelés tekintetében a szezonális változás kevésbé volt nyomon követhető a banai műtárgyban (18. ábra). Itt az iszapterhelést elsősorban a beérkező szennyvíz mennyisége és minősége határozta meg, míg az iszapszerkezet kevésbé befolyásolta a terhelést. Ugyanakkor a téti és győri szennyvíztelepeken látható, hogy a nyári és őszi időszakban, amikor az eleveniszap hőmérséklete magasabb volt, az optimális iszapszerkezet és a nagyobb fajgazdagság miatt az iszapterhelés alacsonyabb volt, mint a hidegebb (tavaszi és téli) időszakban (19., 20. ábra).

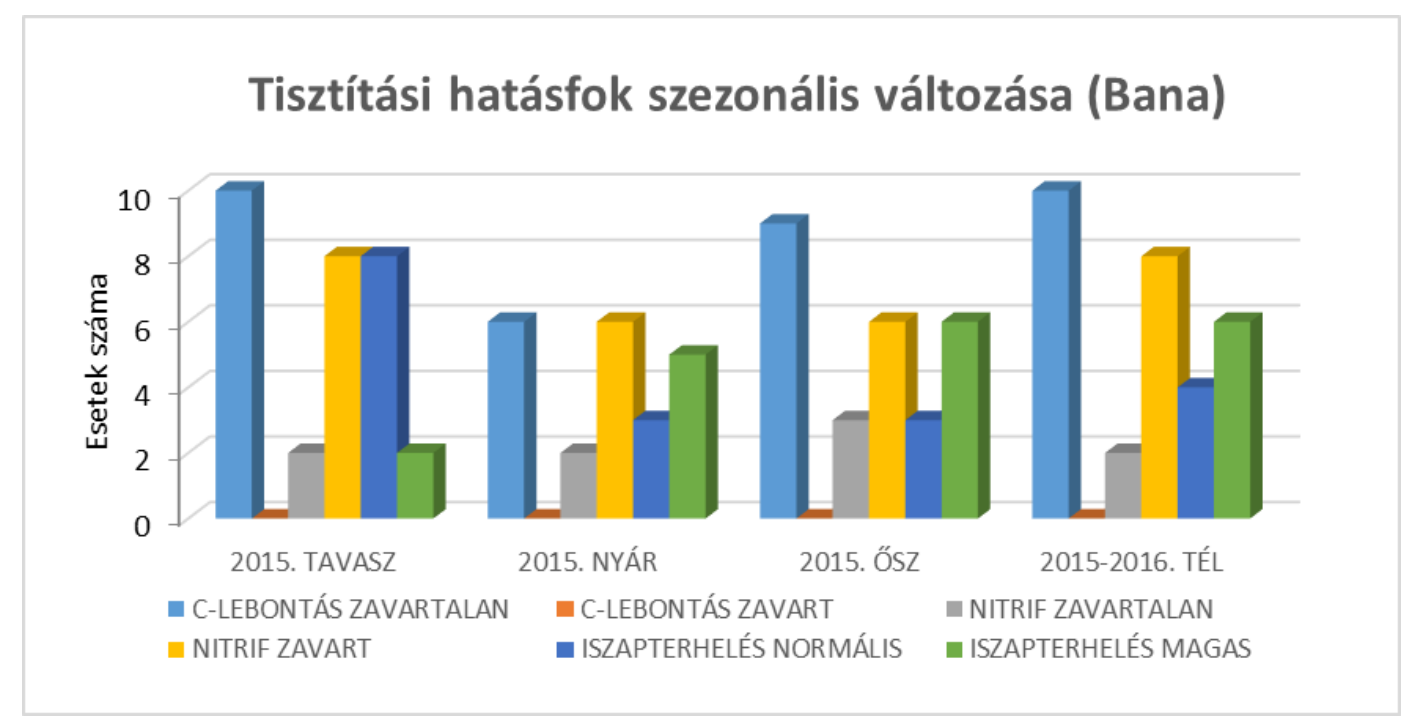

18. ábra: Tisztítási hatásfok szezonális változása, Bana. 


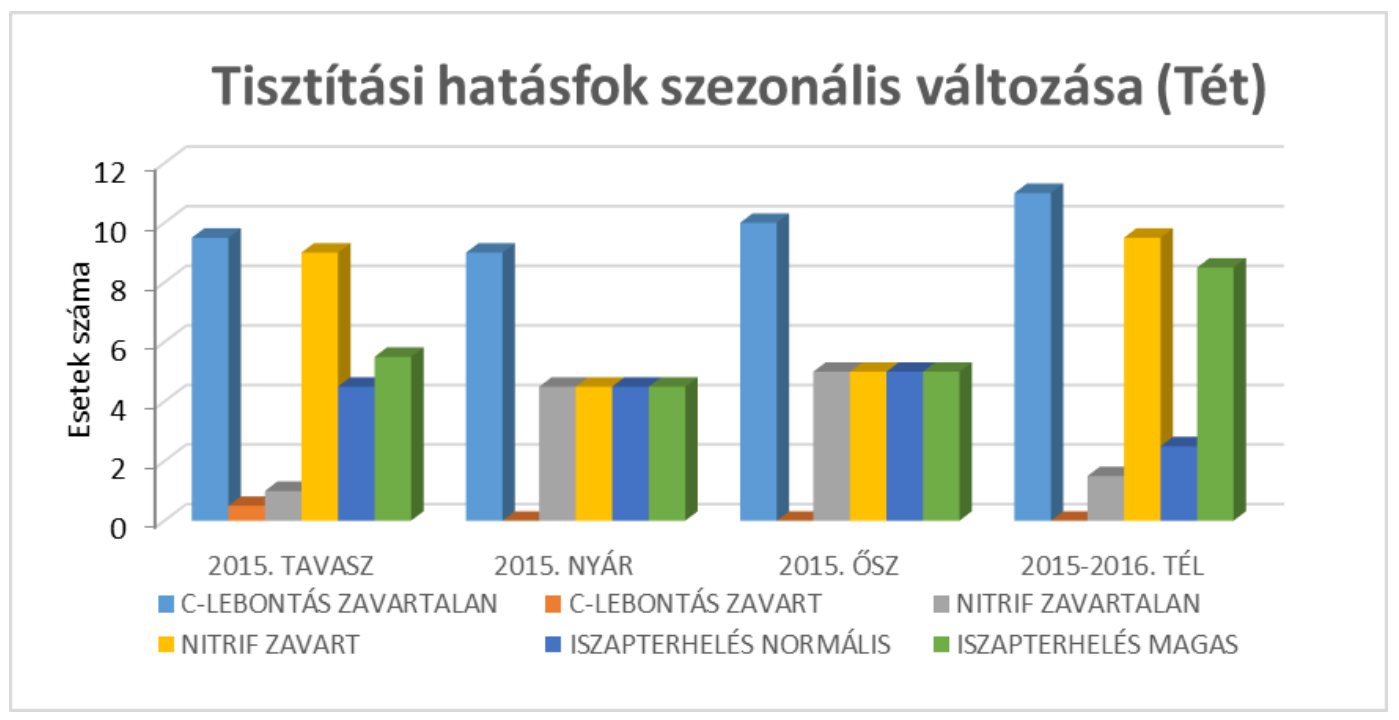

19. ábra: Tisztitási hatásfok szezonális változása, Tét.

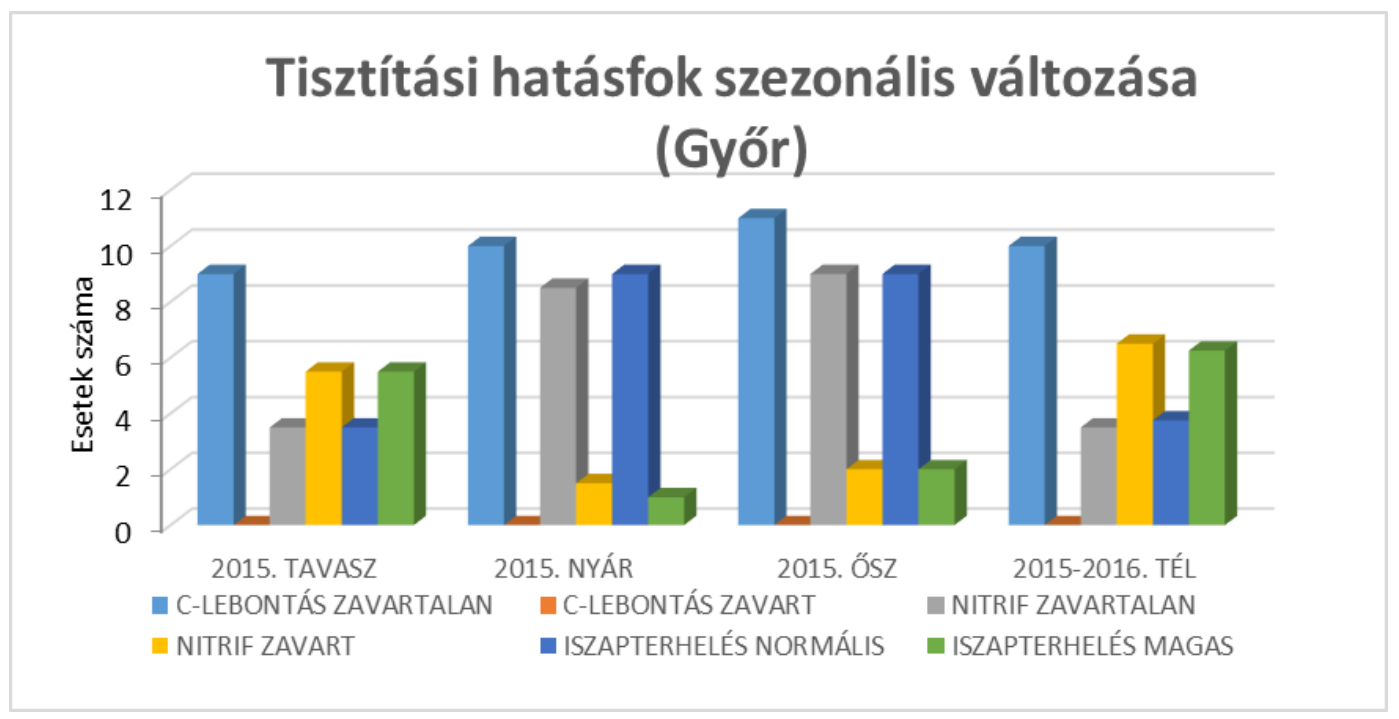

20. ábra: Tisztítási hatásfok szezonális változása, Győrr.

\section{Következtetések}

A szennyvíztisztító telepek eleveniszap közösségének szezonális elemzése során az alábbi megállapításokra jutottunk. Összességében párhuzamot lehet vonni a közösségalkotók szezonális eloszlását mutató diagramok, a fonalasság diagramok, a PCA diagramok, illetve a tisztítási hatásfok diagramok között, hiszen mindegyik ábrán nyomon követhető a közösségalkotók időszakos alakulása. A legmeghatározóbb külső környezeti faktor a hőmérséklet, ez az, ami leginkább befolyásolja a mikrobaközösség-szerkezetet szezonális változását. További befolyásoló tényezők lehetnek a hidraulikai terhelés, a kommunális szennyvíz minőség változása, illetve havária helyzet bekövetkezése. A közösségalkotók eloszlása feltételezésünk szerint tehát leginkább az iszaphőmérséklethez köthető, melyekből következhetnek egyéb üzemeltetési problémák is (pl.: iszapfelúszás). 
A tisztítási hatásfok szezonális változásában a tavaszi-téli illetve a nyári-őszi minták nitrifikáció értékei között párhuzamot lehetett vonni. Ennek az a magyarázata, hogy az eleveniszapban jelen lévő nitrifikáló baktériumok (Nitrosomonas, Nitrobacter) a hőmérsékletre rendkívül érzékenyek, így a hidegebb hónapokban a nitrifikáció nehezebben megy végbe vagy teljes mértékben szünetel. A szénlebontásban szezonális változás nem követhető nyomon, mivel a szénlebontást végző pehelyképző baktériumok a környezeti hőmérsékletre kevésbé érzékenyek.

\section{Hivatkozások}

[1] S. Török (2011) Vízellátás és szennyvízkezelés, Szent István Egyetem, P107.

[2] G. Öllős (1991) Csatornázás - Szennyvíztisztítás I-II.: II. Szennyvíztisztítás, Aqua Kiadó, Budapest, P1299.

[3] Á. Kárpáti - L. Vermes (2011) Vízgazdálkodás - szennyvíztisztítás. - Környezetmérnöki Tudástár 10. kötet, Pannon Egyetem, Környezetmérnöki Intézet, Veszprém. P251.

[4] N. Ushiki - M. Jinno - H. Fujitani - T. Suenaga - A. Terada - S. Tsuneda (2017) Nitrite oxidation kinetics of two Nitrospira strains: The quest for competition and ecological niche differentiation, Journal of Bioscience and Bioengineering Vol. 123(5), 581-589.

[5] M. Alawi - S. Off - M. Kaya - E. Spieck (2009) Temperature influences the population structure of nitrite-oxidizing bacteria in activated sludge, Environmental Microbiology Reports Vol. 1, 184-190.

[6] H. Yu - W. Meng - Y. Song - Z. Tian (2017) Understanding bacterial communities of partial nitritation and nitratation reactors at ambient and low temperature, Chemical Engineering Journal, Vol. 337, 755-763.

[7] B. Young, R. Delatolla, K. Kennedy, E. Laflamme, A. Stintzi, Low temperature MBBR nitrification: Microbiome analysis, Water Research Vol. 111, 224-233., 2017

[8] Á. Serke - F. Bognár (2012) Települési biológiai szennyvíztisztító telepek biológiai folyamatainak optimalizálása a költségcsökkentés szempontjából, Eötvös József Főiskolai Kiadó, Baja, P112.

[9] EMVIR, Egységes Mikrobiológiai Vizsgálati és Értékelő Rendszer (EMVIR) települési eleveniszapos szennyvíztisztító rendszerek fajlagos tisztítási költségének csökkentésére az oldottoxigén-koncentráció és az iszapterhelés szabályozása útján, Szabadalom, EMVIR Nonprofit Kft. , www.emvir.eu

[10] A. Valentín-Vargas - G. Toro-Labrador, A. A. (2012) Massol-Deyá, Bacterial Community Dynamics in Full-Scale Activated Sludge Bioreactors: Operational and Ecological Factors Driving Community Assembly and Performance PLoS ONE Vol. 7(8), e42524. doi:10.1371/journal.pone.0042524.

[11] Módszertani Útmutató az egységes Mikrobiológiai Vizsgálati Rendszer (EMVIR) használatához. 1. kiadás, 1. változat, Budapest, 2009. Szabadalom, www.emvir.eu 
[12] O. Hammer - D. A. T. Harper - P. D. Ryan (2001) Past: Paleontological Statistics Software Package for Education and Data Analysis. Palaeontologia Electronica, Vol. 4(1), 4-9.

[13] S. Rossetti - M. C. Tomei - P. H. Nielsen - V. Tandoi (2005) „Microthrix parvicella”, a filamentous bacterium causing bulking and foaming in activated sludge systems: a review of current knowledge, FEMS Microbiology Reviews Vol. 29, 49-64.

[14] L. L. Blackall - E. M. Seviour - M. A. Cunningham - R. J. Seviour - P. Hugenholtz (1995) "Microthrix parvicella" is a Novel, Deep Branching Member of the Actinomycetes Subphylum, Systematic and Applied Microbiology Vol. 17(4), 513-518.

[15] S. Aruga - Y. Kamagata - T. Kohno - S. Hanada - K. Nakamura - T. Kanagawa (2002) Characterization of filamentous Eikelboom type 021N bacteria and description of Thiothrix disciformis sp. nov. and Thiothrix flexilis sp. nov., International Journal of Systematic and Evolutionary Microbiology Vol. 52(4), 1309-1306.

[16] T. R. Thomsen - B. V. Kjellerup - J. L. Nielsen - P. Hugenholtz - P. H. Nielsen (2000) In situ studies of the phylogeny and physiology of filamentous bacteria with attached growth, Environmental Microbiology Vol. 4, 383-391. 